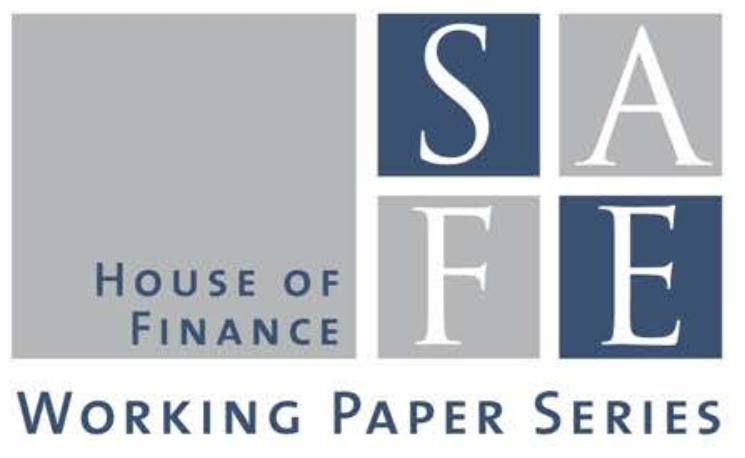

Marcel Grupp

\title{
On the Impact of Leveraged Buyouts on Bank Systemic Risk
}

SAFE Working Paper No. 101

SAFE I Sustainable Architecture for Finance in Europe

A cooperation of the Center for Financial Studies and Goethe University Frankfurt 


\section{Non-Technical Summary}

After the financial crisis, regulatory authorities increased their scrutiny in banking regulation in order to reach again financial stability. One of the focus areas of their new efforts is the leveraged lending market with a specific focus on leveraged buyouts (LBOs). As acknowledged by different U.S. regulators, they see $\mathrm{LBOs}$ as potentially harmful to the financial system.

In addition to banks which are in the center of systemic risk, other institutions can also contribute to it. In the literature, authors already showed the impact of hedge funds and insurance firms on systemic risk. I want to bridge a gap in the literature by analyzing whether LBO loan exposures impact the systemic risk of the banks investing in these loans. Given the high riskiness of the LBO business model and the huge amount of bank-provided debt to finance these deals, it is stunning that the link between LBOs and bank systemic risk has not been emphasized so far.

My paper leads to four major results. First, LBO loan exposures have a significant influence on bank systemic risk with banks having higher levels of systemic risk when financing more LBOs. Second, LBO loans are the only loan purpose that impact systemic risk adversely. Third, several drivers of this impact on systemic risk exist: It increases in the size of the LBO banking network a financial institution is connected to and in the bank size. However, the impact of LBO loan exposure on systemic risk decreases if the bank had a lending relationship with the PE sponsor in the past, more experience in the LBO financing market or a higher credit rating. Finally, the influence of LBO loan exposure on systemic risk cannot only be measured on a cross-sectional level but also on a national level when using a country-wide measure of systemic risk.

My results could provide guidance for regulatory authorities to identify exactly the type of banks that are putting the financial stability with their LBO debt underwriting at risk. These banks are typically well connected, large, less experienced in the LBO market and have lower credit ratings. Additionally, it provides evidence for the recent changes in regulation, increasing the attention on LBO and leveraged lending business. 


\title{
On the Impact of Leveraged Buyouts on Bank Systemic Risk
}

\author{
Marcel Grupp ${ }^{1}$
}

This Version: April 2015

\begin{abstract}
Although banks are at the center of systemic risk, there are other institutions that contribute to it. With the publication of the leveraged lending guideline in March 2013, the U.S. regulators show that they are especially worried about the private equity firms with their high-risk deals. Given these risks and the interconnectedness of the banks through the LBO loan syndicates, I shed light on the impact of a bank's LBO loan exposure on its systemic risk. By using 3,538 observations between 2000 and 2013 from 165 global banks, I show that banks with higher LBO exposure also have a higher level of systemic risk. Other loan purposes do not show this positive relationship. The main drivers influencing this relationship positively are the bank's interconnectedness to other $\mathrm{LBO}$ financing banks and its size. Lending experience with a specific $\mathrm{PE}$ sponsor, experience with leading LBO syndicates or a bank's credit rating, however, lead to a lower impact of the LBO loan exposure on systemic risk.
\end{abstract}

Key Words: Leveraged buyouts, syndicated loans, systemic risk

JEL Classification: G21, G23, G28

I thank Loriana Pelizzon, Sascha Steffen, Uwe Walz and participants at the Systemic Risk Early Warnings and Systemically Important Financial Institutions Seminar in Frankfurt for helpful comments.

\footnotetext{
${ }^{1}$ Goethe University Frankfurt, SAFE Center of Excellence. Address: House of Finance, Theodor-W.-Adorno-Platz 3, 60629 Frankfurt, Germany. Email: marcel.grupp@gmail.com. I gratefully acknowledge research support from the Research Center SAFE, funded by the State of Hessen initiative for research LOEWE.
} 


\section{Introduction}

In the aftermath of the recent financial crisis, regulatory authorities increased their scrutiny in banking regulation (see Moshirian (2011) for a detailed discussion) in order to reach and sustain financial stability. One of the focus areas of the two national bank regulators in the U.S., the Federal Reserve and the OCC (Office of the Comptroller of the Currency), is the leveraged lending market with a specific focus on leveraged buyouts (LBO) and their impact on systemic risk. In order to increase the soundness of the financial system, they published a leveraged lending guideline in March 2013 to reduce the LBO impact on systemic risk as highlighted by the following quote:

"In the letters, the Federal Reserve and the OCC demanded banks [to] comply with [the leveraged lending] guidance published in March 2013 saying they should avoid financing takeover deals that involve putting debt on a company of more than six times its earnings before interest, taxes, depreciation and amortisation, or Ebitda [...]. For banks, the pressure comes as Washington seeks to crack down on behaviour seen as potentially harmful to the broader financial system. [...] "The impact on private equity, a significant driver of what we see as risky practices, is an intended consequence of our actions," Martin Pfinsgraff, the OCC's senior deputy comptroller for large-bank supervision, said in an interview. “2

Although banks are in the focus when thinking about systemic risk (see e.g., Billio et al. (2012)), the quote shows that there are also other institutions that contribute to it. ${ }^{3}$ However, given the attention from regulatory authorities to LBOs and their links to banks, it is stunning that, to my knowledge, the impact of LBO transactions on bank systemic risk has not been investigated at all. As private equity firms are investing in high-risk deals with huge amounts of debt (see Axelson et al. (2013) for a discussion of LBO deal structure and pricing), the risks of financing these deals are higher for banks than the risks from other loan purposes such as normal acquisitions or working capital financing. Together with the fact that LBO financing are typically syndicated to a group of banks that are connected to each other through other loans, the riskiness of LBO deals should have an impact of the systemic risk of the banks.

With this paper, I therefore want to bridge the gap in the literature and answer the research question of what exactly is the impact of LBO loan exposures on the systemic risks of the banks that are invested in these loans. I analyse this question for a cross-section of banks in order to understand reasons and drivers for the systemic risk contribution of a single institution. For my

\footnotetext{
2 See Wall Street Journal 22/01/2014, http://online.wsj.com/news/articles/SB10001424052702304302704579334820201530010

${ }^{3}$ Adams et al. (2014) show for example that hedge funds also play an important role in the transmission of systemic shocks.
} 
analysis I use syndicated loans as they are one of the most important debt sources in LBO deals ${ }^{4}$ and, in contradiction to bonds, are typically hold by banks and not sold to outside investors ${ }^{5}$.

I answer my research question by merging LBO syndicated loan data from Thomson Reuters LPC Dealscan with the systemic expected shortfall measures SRISK and SRISK\% from the NYU V-Lab's Systemic Risk database ending up with 3,538 bank - quarter observations covering a period from 2000 - 2013 which includes the last two major crises, the internet bubble and the financial crisis. SRISK measures a bank's equity shortfall if the entire financial system is in distress defined as a $40 \%$ decline in total banking equity over 6 months and has been developed by Acharya et al. (2010) and Brownlees and Engle (2012). SRISK\% divides SRISK by the total sum of systemic expected shortfall in the dataset. My results lead to four major conclusions:

First, LBO loan exposures have a significant positive influence on the bank's systemic risk which confirms the necessity for the regulatory authorities to keep an eye on the LBO financing industry.

Second, among other loan purposes, LBO loans are the only purpose of syndicated loans that increases both measures of systemic risk used in this paper, absolute systemic expected shortfall (SRISK) and relative systemic expected shortfall (SRISK\%).

Third, several factors explain the impact of LBO loan exposure on systemic risk: It increases in the size of the LBO banking network a financial institution is connected to and in the bank size. This is therefore evidence that LBOs impact systemic risk through the contagion factor in the spirit of Allen and Carletti (2013). However, the impact of LBO loan exposure on systemic risk decreases if the bank had a lending relationship with the PE sponsor in the past, more experience in the LBO financing market or a higher credit rating. The results are robust for correcting for potential endogeneity as it could have been the case that it is the systemic risk influencing the LBO exposure and not vice versa as I claim in this paper. However, my results do emphasize the direction of causality as hypothesised in this paper that LBO exposure influences bank systemic risk.

Finally, the influence of LBO loan exposure on systemic risk can not only be measured on a cross-sectional level but also on a national level. Even if analysing the country-wide systemic risk measure (CATFIN), I can show that the LBO loan exposure aggregated for all banks has a significant influence on the entire financial stability.

\footnotetext{
${ }^{4}$ Axelson et al. (2013) describe LBO deal data where the average LBO transaction is financed by a package of syndicated loans $(88.4 \%$ of total debt) and bonds $(11.6 \%)$

5 "Regulators are far less concerned with bonds issued for these deals, which banks tend not to hold on to." (see Wall Street Journal 22/01/2014, http://online.wsj.com/news/articles/SB10001424052702304302704579334820201530010)
} 
The paper is organized as follows: Section 2 touches briefly upon related literature. Section 3 explains and summarizes the dataset. Section 4 presents the empirical results. Section 5 concludes.

\section{Literature Overview}

Three strands of literature are related to the research question of this paper: the general literature about systemic risk, riskiness of private equity deals and relationships between private equity firms and banks.

As there exist many ideas and definitions of systemic risk, I follow the work of Allen and Carletti (2013) which categorize drivers of systemic risk into four distinct types: i) banking crises due to panics, ii) banking crises due to asset price falls (and common exposures), iii) contagion and iv) foreign exchange mismatches in the banking system. The source of systemic risk described in this paper can be attributed to the contagion factor described by Allen and Carletti (2013).

A good starting point when thinking about how to measure systemic risk is the survey paper by Bisias et al. (2012) which covers the wide range of systemic risk measures that have been developed by researchers, e.g. network measures, macroeconomic measures and cross-sectional measures. It is mainly the latter category of systemic risk measures that are relevant for my research question as I want to analyze the impact of LBO loan exposures on systemic risk for a cross-section of banks. A prominent cross-sectional approach is advocated by Acharya et al. (2010) and Brownlees and Engle (2012) which introduced the Systemic Expected Shortfall (SES) measure. It calculates the propensity to be undercapitalized when the entire financial system is undercapitalized. The authors show that this methodology combines two aspects of systemic risk, the bank's leverage ratio and its expected loss in the tails. Some authors use macroeconomic measures to complement their results derived from cross-sectional variables, a well-known macroeconomic measure is CATFIN which has been presented by Allen et al. (2012). CATFIN is essentially a VaR measure that aggregates three parametric and non-parametric VaR approaches to estimate the systemic risk of the financial sector. It has been developed to improve the forecasts of macroeconomic developments triggered by the risks in the financial sector. When it comes to factors influencing systemic risk, different channels of influence have been analyzed. Loan syndication for example has been shown to play an ambiguous role in explaining systemic risk differences. As Wagner (2010) points out loan syndication might be beneficial for the financial system as it helps banks to diversify their portfolios. Beck and De Jonghe (2013) present a similar idea as they show that industrial sector specialization (which means less diversification of risks) leads to higher stock return volatility and higher levels of systemic risk. This would mean that higher diversification of risks would lead to lower stock return volatility and lower levels of systemic risk. However, there might also be a costs associated with diversification and 
syndication as it increases systemic risks via exposing banks to the same risks. Cai et al. (2014) develop this idea by showing that portfolio similarity based on similar industry exposures leads to higher systemic risks. In another paper, Anginer et al. (2014) analyze the ambiguous role of competition among banks and show that lower competition among banks leads to higher systemic risk as banks have lower incentives to take on diversified risks compared to the high competition case. López-Espinosa et al. (2012) focus on funding and show that banks with higher short-term funding ratios have higher levels of systemic risk which might be explained by a more pronounced interconnectedness of these banks. A similar result has already been analyzed by Rochet and Tirole (1996) which presents evidence that interconnectedness through the interbank market increases financial contagion which leads to "too-big-to-fail"-banks. But there are not only banks contributing to the financial fragility. Billio et al. (2012) show by using principal components analysis and Granger-causality networks that linkages within and across banks, brokers/dealers, insurances and hedge funds increased which could be a source of systemic risk. However, analyzing the directions of the linkages, the authors conclude that banks are still more central to the systemic risk than the other types of institutions. Similarly, Adams et al. (2014) quantify risk spillovers among types of financial institutions (commercial banks, investment banks, hedge funds and insurance companies) by using quantile regressions. They show that shocks have large spillover effects in volatile times and that commercial banks and hedge funds are the main transmitters of shocks to other financial institutions. Focusing on another type of systemic risk drivers, Brunnermeier et al. (2012) show that banks with a higher proportion of noninterest income (such as investment banking fees) have higher systemic risks than traditional deposit-and-lending institutions. De Nicolo and Kwast (2002) analyze the emergence of consolidation among large banks and conclude that more pronounced consolidation leads to higher interdependencies and therefore to higher systemic risk.

The evidence on riskiness of private equity deals in general is rather mixed. Tykvová and Borell (2012) show that financial distress increases after the buyout of a company, but that these firms do not suffer from higher bankruptcy rates than comparable peers which they attribute to the superior distress management skills of private equity firms. Hotchkiss et al. (2014) draw a somewhat different picture by analyzing the drivers of private equity-backed company's distress. They come to the conclusion that PE-backed firms suffer from higher bankruptcy rates and that these higher risks can be fully explained by the higher leverage ratios. Wilson et al. (2012) show that the insolvency ratios have been higher in the earlier years and approached similar values to non-PE-backed companies after 2003. When examining the relationship of PE to financial stability, I am only aware of two rather qualitative papers. Gregory (2013) argue that PE leads to higher corporate sector fragility as a consequence of large debt levels. The main drivers are lower profitability as investments are crowded out by the costs of debt servicing and higher default risks. Acharya et al. (2007) analyze the LBO boom just before the crisis and compared it to the 
LBO boom in the 1980s. They hypothesize that the risks in LBO deals could lead to a dry-up of bank funding resulting in a systemic liquidity crisis. However, as both papers did not analyze this idea in a quantitative manner, I want to bridge that gap.

The final strand of literature related to my work deals with PE firms and their relationships to banks. Ivashina and Kovner (2011) show that borrowing from relationship lenders help reducing information asymmetries which should be very pronounced for LBOs. They conclude that LBOs benefit from lower spreads and looser covenants once they get financed relationship banks. Additionally, LBOs receive even better loan terms, the higher their cross-selling potential. A similar paper has been presented by Bharath et al. (2011) which put the results shown by Ivashina and Kovner (2011) to the more general level: All borrowers benefit from better loan terms once they tap banks with which they have lending relationships. These relationships are more important for intransparent borrowers as in the case of LBO borrowers. Finally, Demiroglu and James (2010) present evidence that reputable PE firms benefit from better loan terms that less-reputable companies. They attribute this finding to two effects: First, reputable firms seem to be better in timing credit markets as they are more active in times of lows spreads and looser lending standards. But more importantly, reputable PE firms reduce agency costs in lending and therefore earn more favorable loan terms such as lower spreads and longer maturities.

\section{Data Set and Descriptive Statistics}

As discussed in the introduction, I want to analyze the impact of leveraged buyout financing on systemic risk for a cross-section of financial institutions by using syndicated loan data. I focus on this credit type as it is the most important source of financing for LBOs (see e.g., Axelson et al. (2013)) and is widely used in academia.

\subsection{Data Set}

My data set builds upon two primary databases, the NYU V-Lab's Systemic Risk and Thomson Reuters LPC Dealscan data. I received the systemic risk measures SRISK and SRISK\% from the NYU V-Lab's Systemic Risk website ${ }^{6}$ and downloaded it on a quarterly frequency for the time period of Q3 2000 (the earliest available start date) until Q4 2013 and for all regions as non-U.S. lenders often invest in U.S. leveraged buyouts. As described in Cai et al. (2014), SRISK is calculated with the following formula:

\footnotetext{
${ }^{6}$ http://vlab.stern.nyu.edu/analysis/RISK.WORLDFIN-MR.GMES
} 


$$
\begin{aligned}
S R I S K & =E[(k(D+M V)-M V) \mid \text { Crisis }] \\
& =k D-(1-k)(1-L R M E S) M V,
\end{aligned}
$$

with $\mathrm{k}$ as prudential capital ratio which is assumed to be $8 \%$ for all regions and $5.5 \%$ for European banks to account for differences in accounting standards, D as book value of debt, LRMES as the long-run marginal expected shortfall which is defined as the co-movement of a bank's equity when the overall banking system equity decreases by $40 \%$ over 6 months and MV as the bank's market value. SRISK\% is then just SRISK divided by the sum of SRISK of all banks in the same quarter to receive a proxy for a bank's systemic risk relative to all other financial institutions.

As a next step, I downloaded all syndicated loans from Dealscan for the same time period and deleted all loans to non-U.S. borrowers. Similar to other authors (e.g., Lim et al. (2014)) I delete all loans to financial borrowers, loans with missing lender information or non-standard loan types ${ }^{7}$ ending up with credit/revolving lines and term loans. As a preparation for the LBO exposure calculation, I use the loan share amount each bank holds in each LBO loan (or proxy it for loans with missing loan share information in Dealscan by dividing the entire LBO loan amount by the number of lenders). The LBO exposure is then the sum per bank of outstanding loan share amounts with the loan purpose "LBO" divided by the total outstanding loan share of the bank irrespective of the loan purpose. This variable is then added to the systemic risk data. As I only analyze U.S. LBO exposure, my results are very conservative as I am likely to underestimate the true LBO exposure effect by only focusing on U.S. LBO financing. The reason for not taking into account LBO deals from other regions is that the detailed loan data is rather scarce for other regions. Additionally, I take only financial institutions - quarter pairs into account with a non-zero amount of outstanding loan share amount (irrespective of the loan purpose). The reason for this lies in the interest of the paper which aims to show the impact of lending exposure to LBOs on systemic risk which cannot be shown for banks not involved in the syndicated loan market. So, I still include observations with zero LBO loan volume but non-zero outstanding loans with other purposes but I delete banks with zero LBO loan volume and zero outstanding loans with other purposes. I end up with 3,538 observations from 165 global financial institutions out of which 77 have their headquarters in North America, 57 in Europe, 25 in Asia, 4 in South America and 2 in Africa. All variables are described in Table 1.

\subsection{Descriptive Statistics}

\footnotetext{
7 This includes bankers acceptance, bridge loans, deferred payment leases, demand loans, bonds, floating rate notes, notes, guarantees, non-committed guidance lines, mortgage facilities, other/undisclosed loans, multi-option facilities, leases and standby/trade letters of credit.
} 
Panel A of Table 2 reports the summary statistics for all variables used in this paper. The financial institutions in my dataset have an average systemic expected shortfall (SRISK) of 18.4 bn USD which translates into an average $1.3 \%$ relative systemic expected shortfall (SRISK\%). When analyzing the distribution of syndicated loan exposure types, $48 \%$ of the entire exposure of a bank is invested in loans with general loan purposes such as working capital, $16 \%$ are invested in takeover loans, $15 \%$ in other loans such as stock buybacks, etc., $12 \%$ in recapitalization loans and only $9 \%$ in LBO loans. Even though LBO loan exposure is a minor category in terms of size relative to the entire portfolio, the increased scrutiny of the regulatory authorities and the results I touched upon already in the introduction show that LBO loans might put banks at risk. 32\% of my dataset are observations stemming from banks classified as systemically important financial institutions by the Financial Stability Board (SIFI bank). The average bank size is 375 bn USD, while the average LBO loan amount is $523 \mathrm{mn}$ USD. The average bank is connected on average to 39 other banks just by its LBO exposure in a given quarter which is close to a quarter of my entire sample of 165 global banks. 25\% of my banks have already invested in an LBO financing to a specific PE sponsor in the last 5 years.

Panel B shows Student's t-tests for my systemic risk measures and differentiates between observations with an LBO exposure below the median of 0.04 and observations above the median. The strongly significant test results in column 4 are first pieces of evidence in favor of my research idea that banks with higher LBO exposure also have a higher level of systemic risk.

Finally, pairwise correlation coefficients of all variables and their significance levels can be found in Panel C. As expected, absolute systemic risk (SRISK) and relative systemic risk (SRISK\%) are strongly correlated with a coefficient of 0.90 , while LBO exposure is weakly correlated with both measures (0.09 and 0.05).

\section{Empirical Results}

In order to analyze the impact of the LBO exposure on a bank's systemic risk, I estimate models with the natural logarithm of SRISK and SRISK\% as dependent variables and the LBO exposure as key independent variable. Additional controls are the interconnectedness to other LBO financing banks, the natural logarithm of the number of LBO events, a dummy indicating when the U.S. is in a recession, the natural logarithm of the bank's total assets, its syndicated loan market share and the high yield spread. All independent variables are lagged by one quarter. Finally, I control for firm fixed effects and cluster the standard errors on a quarterly level to correct for correlations across banks in the same quarter due to common shocks such as e.g. the 
Lehman collapse. The results can be found in Table 3 and indicate a clear positive and highly significant relationship between the LBO exposure and the systemic risk of a bank. I can therefore confirm the view stated in the introductory quotes from the Federal Reserve that banks with higher LBO loan exposures also put the entire financial system at risk. Examining the control variables, I can show that larger banks or banks with higher syndicated loan market share have a higher level of absolute and relative systemic risk, while the number of LBO events in the U.S., the recession dummy and the high yield affect positively only the absolute level of systemic risk.

As a next step, I want to analyze whether LBO exposure is the only exposure type influencing positively the systemic risk and that it does not proxy for other types of loan exposures. Following Carey et al. (1998), I therefore aggregate the other loan purposes to four categories: takeover (e.g., acquisition lines, takeovers, etc.), recapitalization (e.g., dividend recaps, debtor-in-possession), miscellaneous loans (e.g., stock buyback financing, real estate loans, etc.) and general purposes (e.g., working capital). The last category serves as base case, the other three are added to my model. The results can be found in Table 4. The size and significance of the LBO exposure coefficients remain largely unchanged, same applies to the control variables. Takeover exposure is not or barely significant, recapitalization only for the relative systemic risk measure and the miscellaneous exposure coefficients are even significantly negative for the absolute systemic risk measure. LBO exposure therefore drives significantly and positively both types of systemic risk measures and is no proxy for other loan purposes.

After having shown that there is an influence of LBO exposure on a bank's systemic risk, there might be a possibility that it is the level of systemic risk influencing banks in their asset allocation leading to higher LBO exposures and not the other way around which I claim in this paper. As a first step, I report the top 25 financial institutions ranked after their LBO exposure in Panel A of Table 5. Even though there are some systemically important and large banks included in the ranking, the majority of institutions listed in the top 25 are not the largest ones with expected higher systemic risk levels. Interestingly, the top 3 positions are all covered by insurance companies. Panel B shows on a univariate basis that systemically important financial institutions seem to have higher systemic risk levels than the non-SIFI banks. However, if we turn to the multivariate model in Panel C, we can observe two effects. First, the positive influence of LBO exposure on systemic risk comes only from non-SIFI banks, the sum of both LBO exposure coefficients for SIFI banks is not different from zero. Additionally, controlling for size, interconnectedness and other variables, the influence of the SIFI bank dummy on systemic risk is even negative indicating that the SIFI banks do not add additional systemic risk per se. However, it sheds a negative light on the smaller institutions which are not facing the same regulatory scrutiny and have a positive influence on systemic risk with their LBO exposure. 
Finally, Table 6 corrects for endogeneity problems and a potential omitted variable bias by instrumenting the LBO exposure by the average distance of the bank's headquarter from the PE sponsors' headquarters with whom it had lending relationships in the past 5 years (both corrected for potential U.S. offices as described in Table 1) and by the difference in relationship score to the top 3 relationship banks of a specific PE sponsor averaged across all PE sponsors with which a bank is connected. The first instrument measures how close the bank is to their PE sponsors, the last instrument measures how important the bank is for a specific PE sponsor as compared to the top 3 banks for that PE sponsor (measured as average share the top 3 banks financed for a specific PE sponsor as a fraction of the entire amount this PE firm sponsored). The last instrument is in the spirit of Ivashina and Kovner (2011) which used a similar instrument in their paper. As can be seen in the $1^{\text {st }}$ stage regressions, the closer the banks are to the headquarters of the PE sponsors the more likely it is to have a higher LBO exposure, similarly the closer the banks are to the top 3 relationship banks the higher the LBO exposure. Panel A and B show in $2^{\text {nd }}$ stage regressions that the LBO exposure coefficients remain significant and even gain in size compared to the standard model coefficients. The number of observations decreases as I could not find the specific PE sponsor for all loans that have been classified as LBO loan and therefore could not calculate distance or relationship score measures. Columns 6 and 7 show the original OLS models. Concluding this sub-section, I present evidence that the LBO exposure influences bank systemic risk and not vice versa.

As a next step, I want to understand the drivers behind this influence. Therefore, I add to the model from Table 3 interaction terms of the LBO exposure with 7 different potential drivers together with the non-interacted variables. As a first potential driver, I chose the number of relationships to other banks to whom the financial institution is currently connected via LBO financings to capture the impact of contagion risks through large networks. The second variable I analyze in my model is the size of the financial institution as larger banks with larger LBO exposures should also influence the systemic risk to a greater extent than smaller banks. The third variable is the SIFI bank dummy that I already used in Table 5. The fourth variable is a dummy that equals one if the financial institution has a lending relationship with the PE sponsor in the past 5 years to proxy for one aspect of LBO riskiness, the ability of the bank to assess the knowhow of the PE sponsor's management team. This variable is averaged across all outstanding LBO loans of a financial institution in a given quarter. The next potential driver is the ratio of outstanding LBO loans that have been led by the financial institutions to all outstanding LBO loans the financial institution invested in. This variable proxies for the experience and ability to screen and monitor LBO loans and could differentiate good LBO lenders from bad LBO lenders. The sixth variable is the credit rating of the bank as a measure of credit riskiness in order to not confound credit with systemic risk. The last potential driver is the credit rating change for the borrower one month after the loan agreement compared to one month prior loan agreement. As 
I do not have access to other deal riskiness variables, this proxy controls for the inherent risk in the LBO loan for the borrower. Excessive leverage in an LBO should lead to lower credit ratings after loan agreement if it deteriorates the creditworthiness of the borrower.

The results are shown in Table 7. First, larger LBO financing networks translate into higher systemic risks, i.e. banks that are connected to more banks via LBO loans have higher systemic risks stemming from their LBO exposure as the contagion risk from bad LBO deals to the other institutes is higher than for less well connected banks. Second, size matters: larger banks put a higher contagion risk on the financial system and therefore have a stronger positive relationship between LBO exposure and systemic risk. Third, when controlling for other drivers, systemically important financial institutions have no different effect on the influence of LBO exposure on systemic risk than non-SIFI banks. Fourth, LBO experience matters: Banks that have a higher ratio of LBO deals sponsored by a PE firm with whom they built already lending relationships in the past or, fifth, banks that demonstrate that they fully understand the LBO industry by leading more LBO deals than others have a lower impact of LBO exposure on their levels of systemic risk. Sixth, bank credit risk has an influence on the link between the LBO exposure and systemic risk: Banks with a higher credit rating have a lower coefficient on LBO exposure indicating that the relationship between LBO financings and systemic risk is weaker for these banks. Finally, the LBO deal riskiness is related to the influence of LBO exposure on systemic risk but not with the direction of relationship that I expected: banks that experience deterioration of their borrowers' credit ratings (which translates into a negative value of borrower credit rating change pre/post loan) have a weaker relationship between the LBO exposure and systemic risk (although only significant for SRISK). I would have expected the coefficients to be negative in order to capture the idea that higher LBO deal riskiness leads to higher influence of LBO exposure on systemic risk. The wrong sign might be due to an imperfect proxy for LBO deal riskiness as measured by the change in credit rating.

In the robustness tests section, I control for several factors that might bias the influence of LBO exposure on systemic risk, notably other types of fixed effects and autocorrelation. Finally, I analyze whether my results still hold when using US-wide aggregated rather than crosssectional measures of systemic risk.

Table 8 contains a first robustness test as I add rating and time fixed effects to my standard model from Table 3 which does not change the results dramatically.

Table 9 controls for a potential autocorrelation issue by first differencing my standard model. The influence of LBO exposure on systemic risk remains positive and significant.

All pieces of evidences presented in this paper show consistently that banks with higher LBO exposures do also have higher risks for the entire financial system. However, as SRISK and 
SRISK \% are cross-sectional measures of systemic risk, I want to analyze whether similar results can be found when using measure of economy-wide financial fragility. In order to test this I modify my model and use the quarterly CATFIN as a systemic risk measure which I already mentioned in section 2. CATFIN is regressed on the aggregated LBO exposure and several control variables. As the available CATFIN data ends in 2012, the dataset reduces from 54 to 50 observations. As can be seen in Table 10, even on a nation-wide aggregated level, the LBO exposure has a significant positive influence on the systemic risk in the financial industry irrespective of controlling for the other types of loan exposures. I can therefore show that the influence of LBO exposure on systemic risk does not seem to be a zero-sum game when analyzing the entire economy which provides a further rationale for the ongoing tighter regulation of the LBO financing industry.

\section{Conclusion}

In this paper, I shed light on the question of what exactly is the impact of LBO financings on the systemic risk of the banks invested in these loans. To my knowledge, I am the first one to analyze the influence of leveraged buyouts on bank systemic risk with two major contributions:

First, I can show that there is a significant and positive influence of LBO loan exposures on systemic risk. This evidence backs the recent changes in regulatory standards in the leveraged lending industry and helps justifying them. This becomes obvious when comparing LBO loans to other types of syndicated lending such as takeover or recapitalization loans: only LBO loans have a consistent significant and positive impact on systemic risk irrespective of whether I measure systemic risk on a bank- or country-level. Second, my analysis works out the drivers of this relationship which are mainly well-connected, large or low-rated banks with low levels of specific PE sponsor or LBO lead experience. This could therefore guide the regulatory authorities

to identify exactly the type of banks that are putting the financial stability with their LBO debt underwriting at risk.

As regulatory requirements for LBO lending changed just recently, it will be an interesting area for future research to assess whether this policy change will break down the influence of LBO loan exposure on systemic risk. 


\section{References}

Acharya, Viral V., Julian Franks, and Henri Servaes 2007. Private Equity: Boom and Bust? Journal of Applied Corporate Finance, 19, 44-53.

Acharya, Viral V., Lasse H. Pedersen, Thomas Philippon, and Matthew Richardson 2010. Measuring Systemic Risk. Working Paper.

Adams, Zeno, Roland Füss, and Reint Gropp 2014. Spillover Effects among Financial Institutions: A State-Dependent Sensitivity Value-at-Risk Approach. 49, 575-598.

Allen, Franklin, and Elena Carletti 2013. What Is Systemic Risk? Journal of Money, Credit and Banking, 45, 121-127.

Allen, Linda, Turan G. Bali, and Yi Tang 2012. Does Systemic Risk in the Financial Sector Predict Future Economic Downturns? Review of Financial Studies, 25, 3000-3036.

Anginer, Deniz, Asli Demirguc-Kunt, and Min Zhu 2014. How does competition affect bank systemic risk? Journal of Financial Intermediation, 23, 1-26.

Axelson, Ulf, Tim Jenkinson, Per Strömberg, and Michael S. Weisbach 2013. Borrow Cheap, Buy High? The Determinants of Leverage and Pricing in Buyouts. The Journal of Finance, 68, 2223-2267.

Beck, Thorsten, and Olivier De Jonghe 2013. Lending concentration, bank performance and systemic risk : exploring cross-country variation. World Bank Policy Research Working Paper, WPS6604.

Bharath, Sreedhar T., Sandeep Dahiya, Anthony Saunders, and Anand Srinivasan 2011. Lending Relationships and Loan Contract Terms. Review of Financial Studies, 24, 1141-1203.

Billio, Monica, Mila Getmansky, Andrew W. Lo, and Loriana Pelizzon 2012. Econometric measures of connectedness and systemic risk in the finance and insurance sectors. Journal of Financial Economics, 104, 535-559.

Bisias, Dimitrios, Mark Flood, Andrew W. Lo, and Stavros Valavanis 2012. A Survey of Systemic Risk Analytics. U.S. Department of the Treasury Office of Financial Research Working Paper, 0001.

Brownlees, Christian, and Robert Engle 2012. Volatility, Correlation and Tails for Systemic Risk Measurement. Working Paper.

Brunnermeier, Markus, Gang Dong, and Darius Palia 2012. Banks' Non-Interest Income and Systemic Risk. Working Paper.

Cai, Jian, Anthony Saunders, and Sascha Steffen 2014. Syndication, Interconnectedness, and Systemic Risk. Working Paper.

Carey, Mark, Mitch Post, and Steven A. Sharpe 1998. Does Corporate Lending by Banks and Finance Companies Differ? Evidence on Specialization in Private Debt Contracting. The Journal of Finance, 53, 845-878. 
Dass, Nishant, and Massimo Massa 2011. The Impact of a Strong Bank-Firm Relationship on the Borrowing Firm. Review of Financial Studies, 24, 1204-1260.

De Nicolo, Gianni, and Myron L. Kwast 2002. Systemic risk and financial consolidation: Are they related? Journal of Banking $\mathcal{E}$ Finance, 26, 861-880.

Demiroglu, Cem, and Christopher M. James 2010. The role of private equity group reputation in LBO financing. Journal of Financial Economics, 96, 306-330.

Gregory, David 2013. Private equity and financial stability. Quarterly Bulletin 2013 Q1. Bank of England.

Hotchkiss, Edith S., David C. Smith, and Per Strömberg 2014. Private Equity and the Resolution of Financial Distress. Working Paper.

Ivashina, Victoria 2009. Asymmetric information effects on loan spreads. Journal of Financial Economics, 92, 300-319.

Ivashina, Victoria, and Anna Kovner 2011. The Private Equity Advantage: Leveraged Buyout Firms and Relationship Banking. Review of Financial Studies, 24, 2462-2498.

Lim, Jongha, Bernadette A. Minton, and Michael S. Weisbach 2014. Syndicated loan spreads and the composition of the syndicate. Journal of Financial Economics, 111, 45-69.

López-Espinosa, Germán, Antonio Moreno, Antonio Rubia, and Laura Valderrama 2012. Shortterm wholesale funding and systemic risk: A global CoVaR approach. Journal of Banking $\mathcal{E}$ Finance, 36, 3150-3162.

Moshirian, Fariborz 2011. The global financial crisis and the evolution of markets, institutions and regulation. Journal of Banking \& Finance, 35, 502-511.

Rochet, Jean-Charles, and Jean Tirole 1996. Interbank Lending and Systemic Risk. Journal of Money, Credit and Banking, 28, 733-762.

Tykvová, Tereza, and Mariela Borell 2012. Do private equity owners increase risk of financial distress and bankruptcy? Journal of Corporate Finance, 18, 138-150.

Wagner, Wolf 2010. Diversification at financial institutions and systemic crises. Journal of Financial Intermediation, 19, 373-386.

Wilson, Nick, Mike Wright, Donald S. Siegel, and Louise Scholes 2012. Private equity portfolio company performance during the global recession. Journal of Corporate Finance, 18, 193-205. 


\section{Table 1}

Variable Definitions

\begin{tabular}{|c|c|c|}
\hline Variables & Description & Data Source \\
\hline SRISK & $\begin{array}{l}\text { Developed by Acharya et al. (2010) and } \\
\text { Brownlees and Engle (2012), it measures } \\
\text { the capital shortfall of a bank in USD if the } \\
\text { entire system is at distress, defined as a } \\
40 \% \text { decline in aggregate banking equity } \\
\text { over } 6 \text { months }\end{array}$ & $\begin{array}{l}\text { NYU V-Lab's Systemic Risk } \\
\text { database }\end{array}$ \\
\hline SRISK\% & $\begin{array}{l}\text { SRISK divided by the sum of SRISK of the } \\
\text { individual banks in my dataset in the same } \\
\text { quarter }\end{array}$ & $\begin{array}{l}\text { NYU V-Lab's Systemic Risk } \\
\text { database }\end{array}$ \\
\hline Ln [SRISK] & Natural logarithm of SRISK & $\begin{array}{l}\text { NYU V-Lab's Systemic Risk } \\
\text { database }\end{array}$ \\
\hline Ln [SRISK\%] & Natural logarithm of SRISK\% & $\begin{array}{l}\text { NYU V-Lab's Systemic Risk } \\
\text { database }\end{array}$ \\
\hline LBO exposure & $\begin{array}{l}\text { Outstanding loan share amount with } \\
\text { purposes LBO to U.S. non-financial } \\
\text { borrowers and standard loan types such as } \\
\text { term loans and credit lines divided by the } \\
\text { entire outstanding loan share amount to } \\
\text { U.S. non-financial borrowers and standard } \\
\text { loan types }\end{array}$ & $\begin{array}{l}\text { Thomson Reuters LPC } \\
\text { Dealscan }\end{array}$ \\
\hline Ln [number LBO events] & $\begin{array}{l}\text { Natural logarithm of the number of U.S. } \\
\text { LBO events per quarter }\end{array}$ & Preqin \\
\hline NBER recession & $\begin{array}{l}\text { Dummy that equals } 1 \text { if the U.S. economy } \\
\text { has been in a downturn as defined by the } \\
\text { NBER's Business Cycle Dating Committee }\end{array}$ & NBER \\
\hline Ln [total assets] & $\begin{array}{l}\text { Natural logarithm of the financial } \\
\text { institution's total assets }\end{array}$ & $\begin{array}{l}\text { Standard \& Poor's } \\
\text { Compustat, Morningstar or } \\
\text { annual reports }\end{array}$ \\
\hline Syndicated loan market share & $\begin{array}{l}\text { Outstanding loan share amount of a } \\
\text { financial institution divided by the total } \\
\text { outstanding loan share amount of all } \\
\text { financial institutions }\end{array}$ & $\begin{array}{l}\text { Thomson Reuters LPC } \\
\text { Dealscan }\end{array}$ \\
\hline High yield spread & $\begin{array}{l}\text { Difference between the average yield on } \\
\text { the BofA Merrill Lynch U.S. High Yield } \\
100 \text { Index and the U.S. treasury constant } \\
\text { maturity } 3 \text { months rate }\end{array}$ & $\begin{array}{l}\text { Thomson Reuters } \\
\text { Datastream }\end{array}$ \\
\hline General purposes exposure & $\begin{array}{l}\text { Calculation similar to LBO exposure, loan } \\
\text { purposes defined as general purposes: } \\
\text { Capital expenditures, corporate purposes, } \\
\text { equipment purchases, purchase of } \\
\text { hardware and working capital (similar to } \\
\text { Carey et al. (1998)) }\end{array}$ & $\begin{array}{l}\text { Thomson Reuters LPC } \\
\text { Dealscan }\end{array}$ \\
\hline Takeover exposure & $\begin{array}{l}\text { Calculation similar to LBO exposure, loan } \\
\text { purposes defined as takeover purposes: } \\
\text { Acquisition line, MBO, spinoff and } \\
\text { takeover (similar to Carey et al. (1998)) }\end{array}$ & $\begin{array}{l}\text { Thomson Reuters LPC } \\
\text { Dealscan }\end{array}$ \\
\hline
\end{tabular}




\begin{tabular}{|c|c|c|}
\hline Variables & Description & Data Source \\
\hline Recapitalization exposure & $\begin{array}{l}\text { Calculation similar to LBO exposure, loan } \\
\text { purposes defined as recapitalization } \\
\text { purposes: Debt repayment, debtor-in- } \\
\text { possession, dividend recap, exit financing, } \\
\text { IPO related financing and recapitalizations } \\
\text { (similar to Carey et al. (1998)) }\end{array}$ & $\begin{array}{l}\text { Thomson Reuters LPC } \\
\text { Dealscan }\end{array}$ \\
\hline Miscellaneous exposure & $\begin{array}{l}\text { Calculation similar to LBO exposure, loan } \\
\text { purposes defined as miscellaneous } \\
\text { purposes: Aircraft finance, CDO, } \\
\text { commercial paper backup, credit } \\
\text { enhancement, ESOP, lease finance, } \\
\text { mortgage warehouse, project finance, real } \\
\text { estate, securities purchase, ship finance, } \\
\text { stock buyback, trade finance and } \\
\text { other/undisclosed (similar to Carey et al. } \\
(1998) \text { ) }\end{array}$ & $\begin{array}{l}\text { Thomson Reuters LPC } \\
\text { Dealscan }\end{array}$ \\
\hline SIFI bank & $\begin{array}{l}\text { Dummy that equals } 1 \text { if the financial } \\
\text { institution has been classified as global } \\
\text { systemically important bank or insurer }\end{array}$ & Financial Stability Board \\
\hline Count relationships to other banks & $\begin{array}{l}\text { Count of banks with whom the financial } \\
\text { institutions is currently interconnected via } \\
\text { LBO financings }\end{array}$ & $\begin{array}{l}\text { Thomson Reuters LPC } \\
\text { Dealscan }\end{array}$ \\
\hline $\begin{array}{l}\text { Bank sponsor relationship in the past } \\
\text { dummy }\end{array}$ & $\begin{array}{l}\text { Average of a dummy that equals } 1 \text { if the } \\
\text { bank has been a lender for the PE sponsor } \\
\text { in the past } 5 \text { years across all LBO loans of a } \\
\text { financial institution }\end{array}$ & $\begin{array}{l}\text { Thomson Reuters LPC } \\
\text { Dealscan }\end{array}$ \\
\hline Ratio lead to participant investments & $\begin{array}{l}\text { Ratio of outstanding LBO loan share } \\
\text { amount of a financial institution that has } \\
\text { been led by this bank divided by its total } \\
\text { outstanding LBO loan share amount. Lead } \\
\text { arrangers have been identified using the } \\
\text { approach in Ivashina (2009) which defines } \\
\text { banks with the syndicate role of } \\
\text { administrative agent as lead arrangers. If } \\
\text { there is no administrative agent, all } \\
\text { lenders that are agent, arranger, book } \\
\text { runner, lead arranger, lead bank or lead } \\
\text { manager are defined to be the lead } \\
\text { arranger }\end{array}$ & $\begin{array}{l}\text { Thomson Reuters LPC } \\
\text { Dealscan }\end{array}$ \\
\hline Bank credit rating & $\begin{array}{l}\text { Index based on the S\&P long-term } \\
\text { domestic credit rating with low values } \\
\text { indicating bad ratings and high values } \\
\text { high credit ratings }\end{array}$ & $\begin{array}{l}\text { Standard \& Poor's Global } \\
\text { Credit Portal }\end{array}$ \\
\hline $\begin{array}{l}\text { Borrower credit rating change } \\
\text { pre/post loan }\end{array}$ & $\begin{array}{l}\text { Average of the change in the borrower } \\
\text { credit rating index one month prior to one } \\
\text { month after loan closing to proxy for the } \\
\text { riskiness in the loan agreement across all } \\
\text { LBO loans of a financial institution }\end{array}$ & $\begin{array}{l}\text { Standard \& Poor'sGlobal } \\
\text { Credit Portal }\end{array}$ \\
\hline
\end{tabular}




\begin{tabular}{|c|c|c|}
\hline Variables & Description & Data Source \\
\hline CATFIN & $\begin{array}{l}\text { Aggregate systemic risk measure } \\
\text { developed by Allen et al. (2012) } \\
\text { constructed as average of three VaR } \\
\text { measures based on the historical } \\
\text { distribution of equity returns }\end{array}$ & Website of Prof. Turan Bali ${ }^{8}$ \\
\hline Aggregated LBO exposure & $\begin{array}{l}\text { Total outstanding LBO exposure divided } \\
\text { by total outstanding loan exposure }\end{array}$ & $\begin{array}{l}\text { Thomson Reuters LPC } \\
\text { Dealscan }\end{array}$ \\
\hline $\begin{array}{l}\text { Aggregated general purposes } \\
\text { exposure }\end{array}$ & $\begin{array}{l}\text { Total outstanding general purposes } \\
\text { exposure divided by total outstanding } \\
\text { loan exposure, matching of loan purposes } \\
\text { as described above for general purposes } \\
\text { exposure }\end{array}$ & $\begin{array}{l}\text { Thomson Reuters LPC } \\
\text { Dealscan }\end{array}$ \\
\hline Aggregated takeover exposure & $\begin{array}{l}\text { Total outstanding takeover exposure } \\
\text { divided by total outstanding loan } \\
\text { exposure, matching of loan purposes as } \\
\text { described above for takeover exposure }\end{array}$ & $\begin{array}{l}\text { Thomson Reuters LPC } \\
\text { Dealscan }\end{array}$ \\
\hline Aggregated recapitalization exposure & $\begin{array}{l}\text { Total outstanding recapitalization } \\
\text { exposure divided by total outstanding } \\
\text { loan exposure, matching of loan purposes } \\
\text { as described above for recapitalization } \\
\text { exposure }\end{array}$ & $\begin{array}{l}\text { Thomson Reuters LPC } \\
\text { Dealscan }\end{array}$ \\
\hline Aggregated miscellaneous exposure & $\begin{array}{l}\text { Total outstanding miscellaneous exposure } \\
\text { divided by total outstanding loan } \\
\text { exposure, matching of loan purposes as } \\
\text { described above for miscellaneous } \\
\text { exposure }\end{array}$ & $\begin{array}{l}\text { Thomson Reuters LPC } \\
\text { Dealscan }\end{array}$ \\
\hline Aggregated HHI & $\begin{array}{l}\text { Herfindahl-Hirschman index for the } \\
\text { syndicated loan market shares per quarter }\end{array}$ & $\begin{array}{l}\text { Thomson Reuters LPC } \\
\text { Dealscan }\end{array}$ \\
\hline $\begin{array}{l}\mathrm{Ln}[\text { mean distance to PE sponsors of } \\
\text { last } 5 \text { years] }\end{array}$ & $\begin{array}{l}\text { Natural logarithm of the average distance } \\
\text { between the lender headquarter and the } \\
\text { headquarters of the PE sponsors with } \\
\text { whom the lender had lending } \\
\text { relationships in the past } 5 \text { years. In case of } \\
\text { non-U.S. lenders or non-U.S. PE sponsors, } \\
\text { the U.S. office is taken if available, } \\
\text { otherwise New York is assumed to be the } \\
\text { headquarter location. The distance is then } \\
\text { calculated following Dass and Massa } \\
\text { (2011) }\end{array}$ & $\begin{array}{l}\text { Relationships lenders/PE } \\
\text { sponsors: Thomson Reuters } \\
\text { LPC Dealscan, } \\
\text { Headquarters: Thomson } \\
\text { Reuters LPC Dealscan, } \\
\text { Preqin, Standard \& Poor's } \\
\text { Compustat, Bloomberg } \\
\text { Businessweek and company } \\
\text { homepages; Coordinates: } \\
\text { U.S. Board on Geographic } \\
\text { Names or } \\
\text { www.distancesfrom.com }\end{array}$ \\
\hline
\end{tabular}

${ }^{8}$ http://faculty.msb.edu/tgb27/workingpapers.html 


\begin{tabular}{|c|c|c|}
\hline Variables & Description & Data Source \\
\hline $\begin{array}{l}\text { Mean gap PE relationship score to } \\
\text { top } 3 \text { relationship banks }\end{array}$ & $\begin{array}{l}\text { Per PE sponsors, all financial institutions } \\
\text { are ranked by the share the financial } \\
\text { institutions syndicated from the entire } \\
\text { loan amount in the past } 5 \text { years the PE } \\
\text { firm served as sponsor. Then the gap } \\
\text { between the current bank and the top } 3 \\
\text { relationship banks for per PE sponsor is } \\
\text { calculated and then averaged across all PE } \\
\text { sponsors per financial institution. The } \\
\text { methodology is borrowed from Ivashina } \\
\text { and Kovner (2011) }\end{array}$ & $\begin{array}{l}\text { Thomson Reuters LPC } \\
\text { Dealscan }\end{array}$ \\
\hline$\Delta(\ln [\mathrm{SRISK}])$ & First difference of $\ln [$ SRISK] & $\begin{array}{l}\text { NYU V-Lab's Systemic Risk } \\
\text { database }\end{array}$ \\
\hline$\Delta(\ln [\mathrm{SRISK} \%])$ & First difference of $\ln [$ SRISK $\%$ ] & $\begin{array}{l}\text { NYU V-Lab's Systemic Risk } \\
\text { database }\end{array}$ \\
\hline$\Delta($ LBO exposure $)$ & First difference of the LBO exposure & $\begin{array}{l}\text { Thomson Reuters LPC } \\
\text { Dealscan }\end{array}$ \\
\hline$\Delta$ (Count relationships to other banks) & $\begin{array}{l}\text { First difference of count relationships to } \\
\text { other banks }\end{array}$ & $\begin{array}{l}\text { Thomson Reuters LPC } \\
\text { Dealscan }\end{array}$ \\
\hline$\Delta(\ln [$ number LBO events $])$ & First difference of $\ln$ [number LBO events] & Preqin \\
\hline$\Delta$ (NBER recession) & $\begin{array}{l}\text { First difference of the NBER recession } \\
\text { dummy }\end{array}$ & NBER \\
\hline$\Delta(\ln [$ total assets $])$ & First difference of $\ln$ [total assets] & $\begin{array}{l}\text { Standard \& Poor's } \\
\text { Compustat, Morningstar or } \\
\text { annual reports }\end{array}$ \\
\hline$\Delta$ (syndicated loan market share) & $\begin{array}{l}\text { First difference of the syndicated loan } \\
\text { market share }\end{array}$ & $\begin{array}{l}\text { Thomson Reuters LPC } \\
\text { Dealscan }\end{array}$ \\
\hline$\Delta$ (high yield spread) & First difference of the high yield spread & $\begin{array}{l}\text { Thomson Reuters } \\
\text { Datastream }\end{array}$ \\
\hline
\end{tabular}




\section{Table 2}

Descriptive Statistics

Panel A contains descriptive statistics, Panel B Student's t-tests of the systemic risk measures for LBO exposures above and below median, Panel C a correlation matrix. Definitions of all variables can be found in Table $1 . * * * *$, and ${ }^{*}$ correspond to the statistical significance levels of $1 \%, 5 \%$ and $10 \%$, respectively.

\section{Panel A}

\begin{tabular}{|c|c|c|c|c|c|c|}
\hline & Obs & Mean & SD & $25^{\text {th }}$ Percentile & Median & $75^{\text {th }}$ Percentile \\
\hline \multicolumn{7}{|l|}{ Variables used for standard models } \\
\hline SRISK (in mn USD) & 3,538 & 18,444 & 27,199 & 2,240 & 7,410 & 22,144 \\
\hline SRISK\% & 3,538 & 1.29 & 1.67 & 0.18 & 0.56 & 1.71 \\
\hline Ln [SRISK] & 3,538 & 8.75 & 1.71 & 7.71 & 8.91 & 10.01 \\
\hline Ln [SRISK\%] & 3,538 & -0.74 & 1.70 & -1.71 & -0.58 & 0.54 \\
\hline LBO exposure & 3,538 & 0.09 & 0.16 & 0.00 & 0.04 & 0.11 \\
\hline Number LBO events & 3,538 & 282 & 122 & 219 & 290 & 371 \\
\hline Ln [Number LBO events] & 3,538 & 5.50 & 0.59 & 5.39 & 5.67 & 5.92 \\
\hline NBER recession & 3,538 & 0.23 & 0.42 & 0.00 & 0.00 & 0.00 \\
\hline Total Assets (in mn USD) & 3,538 & 375,324 & 641,184 & 13 & 52,725 & 457,410 \\
\hline Ln [total assets] & 3,538 & 12.40 & 1.53 & 11.56 & 12.57 & 13.53 \\
\hline Syndicated loan market share & 3,538 & 0.01 & 0.02 & 0.00 & 0.00 & 0.01 \\
\hline High yield spread & 3,538 & 7.02 & 2.43 & 5.98 & 6.96 & 7.84 \\
\hline General purposes exposure & 3,538 & 0.48 & 0.29 & 0.25 & 0.52 & 0.69 \\
\hline Takeover exposure & 3,538 & 0.16 & 0.16 & 0.02 & 0.14 & 0.21 \\
\hline Recapitalization exposure & 3,538 & 0.12 & 0.19 & 0.00 & 0.06 & 0.14 \\
\hline Miscellaneous exposure & 3,538 & 0.15 & 0.22 & 0.02 & 0.08 & 0.18 \\
\hline SIFI bank & 3,538 & 0.32 & 0.47 & 0.00 & 0.00 & 1.00 \\
\hline Count relationships to other banks & 1,875 & 39 & 19 & 21 & 42 & 54 \\
\hline Bank sponsor relationship in the past dummy & 1,875 & 0.25 & 0.21 & 0.00 & 0.24 & 0.41 \\
\hline
\end{tabular}

(continued) 
Table 2 Panel A - continued

\begin{tabular}{|c|c|c|c|c|c|c|}
\hline Ratio lead to participant investments & 1,875 & 0.20 & 0.23 & 0.00 & 0.09 & 0.40 \\
\hline Bank credit rating & 1,875 & 13.04 & 3.10 & 13.00 & 14.00 & 15.00 \\
\hline Borrower credit rating change pre/post loan & 1,875 & 0.02 & 0.18 & -0.03 & 0.00 & 0.04 \\
\hline \multicolumn{7}{|l|}{ Variables used for US-wide aggregated model } \\
\hline CATFIN & 50 & 0.27 & 0.15 & 0.15 & 0.21 & 0.36 \\
\hline Aggregated LBO exposure & 50 & 0.08 & 0.03 & 0.05 & 0.06 & 0.12 \\
\hline Aggregated general purposes exposure & 50 & 0.48 & 0.15 & 0.37 & 0.57 & 0.59 \\
\hline Aggregated takeover exposure & 50 & 0.18 & 0.05 & 0.16 & 0.16 & 0.20 \\
\hline Aggregated recapitalization exposure & 50 & 0.14 & 0.09 & 0.07 & 0.10 & 0.20 \\
\hline Aggregated miscellaneous exposure & 50 & 0.11 & 0.05 & 0.06 & 0.11 & 0.17 \\
\hline Aggregated HHI & 50 & 0.04 & 0.01 & 0.04 & 0.04 & 0.05 \\
\hline \multicolumn{7}{|l|}{ Variables used for IV estimation } \\
\hline Mean distance to PE sponsors of last 5 years in miles & 2,050 & 663 & 347 & 495 & 593 & 732 \\
\hline Ln [mean distance to PE sponsors of last 5 years] & 2,050 & 6.25 & 1.13 & 6.20 & 6.39 & 6.60 \\
\hline Mean gap PE relationship score to top 3 relationship banks & 2,050 & 0.06 & 0.03 & 0.03 & 0.06 & 0.07 \\
\hline \multicolumn{7}{|l|}{ Variables used for autocorrelation test } \\
\hline$\Delta(\ln [$ SRISK] $)$ & 3,373 & 0.03 & 0.66 & -0.17 & 0.00 & 0.19 \\
\hline$\Delta(\ln \%[S R I S K \%])$ & 3,373 & -0.01 & 0.61 & -0.18 & -0.01 & 0.13 \\
\hline$\Delta(\mathrm{LBO}$ exposure $)$ & 3,373 & 0.00 & 0.03 & 0.00 & 0.00 & 0.00 \\
\hline$\Delta(\ln [$ [number LBO events] $)$ & 3,373 & 0.04 & 0.29 & -0.10 & 0.04 & 0.18 \\
\hline$\Delta($ NBER recession) & 3,373 & -0.01 & 0.28 & 0.00 & 0.00 & 0.00 \\
\hline$\Delta($ ln $[$ total assets] $)$ & 3,373 & 0.02 & 0.11 & 0.00 & 0.00 & 0.02 \\
\hline$\Delta($ syndicated loan market share) & 3,373 & 0.00 & 0.00 & 0.00 & 0.00 & 0.00 \\
\hline$\Delta($ high yield spread $)$ & 3,373 & -0.01 & 1.36 & -0.71 & -0.20 & 0.37 \\
\hline
\end{tabular}


Panel B

\begin{tabular}{lccc}
\hline & Average for LBO exposure below median (1) & Average for LBO exposure above median (2) & Difference (2) - (1) \\
\hline Ln [SRISK] & 8.20 & 9.30 & -0.29 \\
Ln [SRISK\%] & -1.19 & $1.10^{* * *}$ & 1,769 \\
\hline Observations & 1,769 & $0.90^{* * *}$ & \\
\hline
\end{tabular}

Panel C

\begin{tabular}{|c|c|c|c|c|c|c|}
\hline & Ln [SRISK] & $\begin{array}{c}\text { Ln } \\
\text { [SRISK\%] }\end{array}$ & $\begin{array}{c}\text { LBO } \\
\text { exposure }\end{array}$ & $\begin{array}{l}\text { Ln [Number } \\
\text { LBO events] }\end{array}$ & NBER recession & $\begin{array}{c}\text { Ln [total } \\
\text { assets] }\end{array}$ \\
\hline Ln [SRISK] & 1.0000 & & & & & \\
\hline Ln [SRISK\%] & $0.9016^{* * *}$ & 1.0000 & & & & \\
\hline LBO exposure & $0.0906^{* * *}$ & $0.0471^{* * *}$ & 1.0000 & & & \\
\hline Ln [Number LBO events] & $0.2291^{* * *}$ & $-0.0864^{* * *}$ & $0.1291^{* * *}$ & 1.0000 & & \\
\hline NBER recession & 0.0040 & $-0.0525^{* * *}$ & 0.0017 & $-0.2499^{* * *}$ & 1.0000 & \\
\hline Ln [total assets] & $0.7478^{* * *}$ & $0.6790^{* * *}$ & $0.0642^{* * *}$ & $0.2428^{* * *}$ & $-0.0529^{* * *}$ & 1.0000 \\
\hline Syndicated loan market share & $0.4024^{* * *}$ & $0.4116^{* * *}$ & 0.0157 & -0.0016 & -0.0008 & $0.4287^{* * *}$ \\
\hline High yield spread & $-0.0763^{* * *}$ & $-0.1166^{* * *}$ & $-0.0652^{* * *}$ & $-0.4730^{* * *}$ & $0.2145^{* * *}$ & $-0.1668^{* * *}$ \\
\hline General purposes exposure & $0.1259^{* * *}$ & $-0.0493^{* * *}$ & $-0.3133^{* * *}$ & $0.4171^{* * *}$ & $-0.0325^{*}$ & $0.1778^{* * *}$ \\
\hline Takeover exposure & $-0.1223^{* * *}$ & $-0.0377^{* *}$ & $-0.0518^{* * *}$ & $-0.2574^{* * *}$ & $0.0681^{* * *}$ & $-0.0971^{* * *}$ \\
\hline Recapitalization exposure & $-0.1046^{* * *}$ & $0.0545^{* * *}$ & $-0.0950^{* * *}$ & $-0.3730^{* *}$ & 0.0152 & $-0.1390^{* * *}$ \\
\hline Miscellaneous exposure & $-0.0516^{* * *}$ & 0.0104 & $-0.2077^{* * *}$ & $-0.1302^{* *}$ & -0.0219 & $-0.0889^{* * *}$ \\
\hline SIFI bank & $0.5551^{* * *}$ & $0.5528^{* * *}$ & $0.1788^{* * *}$ & $0.0638^{* * *}$ & $-0.0480^{* * *}$ & $0.6154^{* * *}$ \\
\hline Count relationships to other banks & $0.4842^{* * *}$ & $0.4709^{* * *}$ & $0.2025^{* * *}$ & $0.0865^{* * *}$ & $0.0373^{* *}$ & $0.4893^{* * *}$ \\
\hline Bank sponsor relationship in the past dummy & $0.3126^{* * *}$ & $0.3295^{* * *}$ & $-0.0379^{*}$ & -0.0139 & $-0.0371^{*}$ & $0.3333^{* * *}$ \\
\hline Ratio lead to participant investments & $0.3265^{* * *}$ & $0.3431^{* * *}$ & $0.1109^{* * *}$ & 0.0049 & $-0.0307^{*}$ & $0.3825^{* * *}$ \\
\hline Bank credit rating & $0.4210^{* * *}$ & $0.4197^{* * *}$ & $0.0383^{* *}$ & $0.0579^{* * *}$ & $0.0666^{* * *}$ & $0.4800^{* * *}$ \\
\hline Borrower credit rating change pre/post loan & $0.0699^{* * *}$ & $0.1607^{* * *}$ & $-0.1366^{* * *}$ & $-0.1782^{* * *}$ & $-0.0447^{* *}$ & $0.0552^{* *}$ \\
\hline Average LBO loan amount (in mn USD) & $0.2305^{* * *}$ & $0.1686^{* * *}$ & $-0.0356^{*}$ & $0.1189^{* * *}$ & -0.0274 & $0.1343^{* * *}$ \\
\hline
\end{tabular}




\begin{tabular}{|c|c|c|c|c|c|c|c|}
\hline & $\begin{array}{c}\text { Syndicated } \\
\text { loan market } \\
\text { share }\end{array}$ & $\begin{array}{c}\text { High yield } \\
\text { spread }\end{array}$ & $\begin{array}{c}\text { General } \\
\text { purposes } \\
\text { exposure }\end{array}$ & $\begin{array}{l}\text { Takeover } \\
\text { exposure }\end{array}$ & $\begin{array}{c}\text { Recapitalization } \\
\text { exposure }\end{array}$ & $\begin{array}{c}\text { Miscellaneous } \\
\text { exposure }\end{array}$ & \\
\hline Syndicated loan market share & 1.0000 & & & & & & \\
\hline High yield spread & $-0.0298^{*}$ & 1.0000 & & & & & \\
\hline General purposes exposure & $0.0654^{* * *}$ & $-0.1582^{* * *}$ & 1.0000 & & & & \\
\hline Takeover exposure & 0.0218 & $0.1392^{* *}$ & $-0.3472^{* * *}$ & 1.0000 & & & \\
\hline Recapitalization exposure & -0.0042 & $0.1209^{* * *}$ & $-0.4587^{* * *}$ & $-0.0444^{* * *}$ & 1.0000 & & \\
\hline Miscellaneous exposure & $-0.1095^{* * *}$ & $0.0486^{* * *}$ & $-0.4270^{* * *}$ & $-0.2025^{* * *}$ & $-0.1609^{* * *}$ & 1.0000 & \\
\hline SIFI bank & $0.4625^{* * *}$ & $-0.0635^{* * *}$ & $0.0670^{* * *}$ & $-0.0568^{* * *}$ & $-0.0612^{* * *}$ & $-0.1252^{* * *}$ & \\
\hline Count relationships to other banks & $0.6485^{* * *}$ & $-0.1002^{* * *}$ & 0.0160 & $0.1371^{* *}$ & $-0.0480^{* * *}$ & $-0.2295^{* * *}$ & \\
\hline Bank sponsor relationship in the past dummy & $0.6769^{* * *}$ & -0.0265 & -0.0114 & $0.0879^{* * *}$ & $0.0824^{* * *}$ & $-0.0742^{* * *}$ & \\
\hline Ratio lead to participant investments & $0.6944^{* * *}$ & $-0.0464^{* * *}$ & 0.0089 & $0.0492^{* * *}$ & -0.0092 & $-0.1216^{* * *}$ & \\
\hline Bank credit rating & $0.2414^{* * *}$ & $-0.1027^{* * *}$ & $0.1335^{* * *}$ & $0.0414^{* *}$ & 0.0062 & $-0.2388^{* * *}$ & \\
\hline Borrower credit rating change pre/post loan & $0.0622^{* * *}$ & $0.0520^{* *}$ & $-0.1122^{* * *}$ & $0.1177^{* * *}$ & $0.1558^{* * *}$ & $0.1775^{* * *}$ & \\
\hline \multirow[t]{2}{*}{ Average LBO loan amount (in mn USD) } & $0.1083^{* * *}$ & -0.0173 & $0.1125^{* * *}$ & $-0.1199 * * *$ & $-0.1933^{* * *}$ & $0.1187^{* * *}$ & \\
\hline & SIFI bank & $\begin{array}{c}\text { Count } \\
\text { relationships } \\
\text { to other } \\
\text { banks }\end{array}$ & $\begin{array}{l}\text { Bank sponsor } \\
\text { relationship } \\
\text { in the past } \\
\text { dummy }\end{array}$ & $\begin{array}{c}\text { Ratio lead to } \\
\text { participant } \\
\text { investments }\end{array}$ & $\begin{array}{c}\text { Bank credit } \\
\text { rating }\end{array}$ & $\begin{array}{c}\text { Borrower } \\
\text { credit rating } \\
\text { change pre/ } \\
\text { post loan }\end{array}$ & $\begin{array}{c}\text { Average } \\
\text { LBO } \\
\text { loan } \\
\text { amount } \\
\text { (in mn } \\
\text { USD) }\end{array}$ \\
\hline SIFI bank & 1.0000 & & & & & & \\
\hline Count relationships to other banks & $0.4301^{* * *}$ & 1.0000 & & & & & \\
\hline Bank sponsor relationship in the past dummy & $0.2368^{* * *}$ & $0.7406^{* * *}$ & 1.0000 & & & & \\
\hline Ratio lead to participant investments & $0.3995^{* * *}$ & $0.6314^{* * *}$ & $0.6142^{* * *}$ & 1.0000 & & & \\
\hline Bank credit rating & $0.3641^{* * *}$ & $0.3825^{* * *}$ & $0.1326^{* * *}$ & $0.2448^{* * *}$ & 1.0000 & & \\
\hline Borrower credit rating change pre/post loan & $0.1067^{* * *}$ & $0.1021^{* * *}$ & $0.1233^{* * *}$ & $0.0540^{* *}$ & $0.1170^{* * *}$ & 1.0000 & \\
\hline Average LBO loan amount (in mn USD) & $0.0499^{* *}$ & $0.1351^{* * *}$ & $0.0742^{* * *}$ & $0.1189^{* * *}$ & $0.1661^{* * *}$ & $-0.1315^{* * *}$ & 1.0000 \\
\hline
\end{tabular}




\section{Table 3}

Impact of LBO Exposure on Systemic Risk

This table presents the coefficient estimates of OLS regressions. Definitions of all variables can be found in Table 1. Standard errors are clustered by quarter to correct for correlations across banks in the same quarter due to common shocks. ${ }^{* *},{ }^{* *}$, and ${ }^{*}$ correspond to the statistical significance levels of $1 \%, 5 \%$ and $10 \%$, respectively.

\begin{tabular}{|c|c|c|c|c|}
\hline \multirow[b]{2}{*}{ Variables } & \multicolumn{2}{|c|}{ Ln [SRISK] } & \multicolumn{2}{|c|}{ Ln [SRISK\%] } \\
\hline & Coef. & Se. & Coef. & Se. \\
\hline LBO exposure & $0.35^{* * *}$ & $(0.11)$ & $0.24^{* *}$ & $(0.11)$ \\
\hline \multicolumn{5}{|l|}{ Controls } \\
\hline Count relationships to other banks & 0.00 & $(0.00)$ & 0.00 & $(0.00)$ \\
\hline Ln [number LBO events] & $0.29^{* * *}$ & $(0.08)$ & $-0.59^{* * *}$ & $(0.07)$ \\
\hline NBER recession & $0.26^{* * *}$ & $(0.09)$ & -0.11 & $(0.07)$ \\
\hline Ln [total assets] & $1.42^{* * *}$ & $(0.07)$ & $0.85^{* * *}$ & $(0.08)$ \\
\hline Syndicated loan market share & $18.58^{* * *}$ & (3.33) & $16.68^{* * *}$ & $(3.88)$ \\
\hline High yield spread & $0.13^{* * *}$ & $(0.01)$ & -0.01 & $(0.01)$ \\
\hline Firm fixed effects & \multicolumn{2}{|c|}{ Yes } & \multicolumn{2}{|l|}{ Yes } \\
\hline Observations & \multicolumn{2}{|c|}{3,538} & \multicolumn{2}{|l|}{3,538} \\
\hline Adjusted R-squared & \multicolumn{2}{|c|}{0.85} & \multicolumn{2}{|l|}{0.86} \\
\hline
\end{tabular}




\section{Table 4}

Impact of LBO Exposure on Systemic Risk Compared to Other Exposures

This table presents the coefficient estimates of OLS regressions. Definitions of all variables can be found in Table 1. Standard errors are clustered by quarter to correct for correlations across banks in the same quarter due to common shocks. ${ }^{* *},{ }^{* *}$, and ${ }^{*}$ correspond to the statistical significance levels of $1 \%, 5 \%$ and $10 \%$, respectively.

\begin{tabular}{|c|c|c|c|c|}
\hline \multirow[b]{2}{*}{ Variables } & \multicolumn{2}{|c|}{ Ln [SRISK] } & \multicolumn{2}{|c|}{ Ln [SRISK\%] } \\
\hline & Coef. & Se. & Coef. & Se. \\
\hline LBO exposure & $0.33^{* * *}$ & $(0.12)$ & $0.32^{* *}$ & $(0.12)$ \\
\hline \multicolumn{5}{|l|}{$\underline{\text { Controls }}$} \\
\hline Takeover exposure & -0.20 & $(0.20)$ & $0.35^{*}$ & $(0.20)$ \\
\hline Recapitalization exposure & 0.07 & $(0.10)$ & $0.35^{* * *}$ & $(0.09)$ \\
\hline Miscellaneous exposure & $-0.50^{* * *}$ & $(0.16)$ & -0.06 & $(0.15)$ \\
\hline Count relationships to other banks & 0.00 & $(0.00)$ & 0.00 & $(0.00)$ \\
\hline Ln [number LBO events] & $0.27^{* * *}$ & $(0.08)$ & $-0.54^{* * *}$ & $(0.07)$ \\
\hline NBER recession & $0.26^{* * *}$ & $(0.08)$ & -0.10 & $(0.07)$ \\
\hline Ln [total assets] & $1.40^{* * *}$ & $(0.07)$ & $0.87^{* * *}$ & $(0.07)$ \\
\hline Syndicated loan market share & $17.63^{* * *}$ & $(3.20)$ & $16.30^{* * *}$ & $(3.76)$ \\
\hline High yield spread & $0.13^{* * *}$ & $(0.01)$ & -0.01 & $(0.01)$ \\
\hline Firm fixed effects & \multicolumn{2}{|c|}{ Yes } & \multicolumn{2}{|c|}{ Yes } \\
\hline Observations & \multicolumn{2}{|c|}{3,538} & \multicolumn{2}{|c|}{3,538} \\
\hline Adjusted R-squared & \multicolumn{2}{|c|}{0.85} & \multicolumn{2}{|c|}{0.86} \\
\hline
\end{tabular}




\section{Table 5}

Institutions Driving Impact of LBO Exposure on Systemic Risk

Panel A shows the 25 financial institutions ranked after LBO exposure. Panel B presents Student's t-tests with the systemic risk measures differentiated between SIFI and non-SIFI banks. Panel C re-estimates Table 3 and adds an interaction of LBO exposure and the SIFI bank dummy. Definitions of all variables can be found in Table 1. Standard errors are clustered by quarter to correct for correlations across banks in the same quarter due to common shocks. ${ }^{* * *},{ }^{* *}$, and ${ }^{*}$ correspond to the statistical significance levels of $1 \%, 5 \%$ and $10 \%$, respectively.

\section{Panel A}

\begin{tabular}{lll}
\hline Rank & Financial Institution & SIFI bank \\
\hline 1 & AXA SA & Yes \\
2 & Protective Life Corp & No \\
3 & Prudential PLC & Yes \\
4 & IKB Deutsche Industriebank AG & No \\
5 & Hartford Financial Services Group Inc & No \\
6 & Intermediate Capital Group PLC & No \\
7 & American Capital Ltd & No \\
8 & Itau Unibanco Holding SA & No \\
9 & MetLife Inc & Yes \\
10 & Jefferies Group Inc & No \\
11 & Standard Bank Group Ltd & No \\
12 & Banco do Brasil SA & No \\
13 & DVB Bank SE & No \\
14 & CapitalSource Inc & No \\
15 & Bank of Ireland & No \\
16 & Goldman Sachs Group Inc & Yes \\
17 & Dexia SA & No \\
18 & Lehman Brothers & No \\
19 & American International Group Inc & Yes \\
20 & ORIX Corp & No \\
21 & Natixis & No \\
22 & Morgan Stanley & Yes \\
23 & Bear Stearns & No \\
24 & Sun Life Financial Inc & No \\
25 & Banco Espirito Santo SA & No \\
\hline & & \\
\hline
\end{tabular}


Panel B

\begin{tabular}{lccc}
\hline & Non-SIFI bank (1) & SIFI bank (2) & Difference (2) - (1) \\
\hline Ln [SRISK] & 8.11 & 10.14 & $2.04^{* * *}$ \\
Ln [SRISK\%] & -1.38 & 0.64 & $2.02^{* * *}$ \\
\hline Observations & 2,415 & 1,123 & \\
\hline
\end{tabular}

\section{Panel C}

\begin{tabular}{lcccc}
\hline & \multicolumn{2}{c}{ Ln [SRISK] } & \multicolumn{2}{c}{ Ln [SRISK\%] } \\
Variables & Coef. & Se. & Coef. & Se. \\
\hline & & & & \\
LBO exposure (1) & $0.47^{* * *}$ & $(0.13)$ & $0.32^{* *}$ & $(0.13)$ \\
Interaction: LBO exposure \& SIFI bank (2) & $-0.41^{* *}$ & $(0.16)$ & $-0.30^{* *}$ & $(0.15)$ \\
& & & & \\
Controls & & & & \\
SIFI bank & $-3.46^{* * *}$ & $(0.50)$ & $-2.68^{* * *}$ & $(0.47)$ \\
Count relationships to other banks & 0.00 & $(0.00)$ & 0.00 & $(0.00)$ \\
Ln [number LBO events] & $0.29^{* * *}$ & $(0.08)$ & $-0.59^{* * *}$ & $(0.07)$ \\
NBER recession & $0.26^{* * *}$ & $(0.09)$ & -0.11 & $(0.07)$ \\
Ln [total assets] & $1.42^{* * *}$ & $(0.07)$ & $0.85^{* * *}$ & $(0.08)$ \\
Syndicated loan market share & $19.00^{* * *}$ & $(3.34)$ & $17.00^{* * *}$ & $(3.89)$ \\
High yield spread & $0.13^{* * *}$ & $(0.01)$ & -0.01 & $(0.01)$ \\
Firm fixed effects & Yes & & & Yes \\
\hline Observations & 3,538 & & 3,538 & \\
P-value test: $(1)+(2)=0$ & 0.68 & & 0.89 & \\
Adjusted R-squared & 0.86 & & & \\
\hline
\end{tabular}




\section{Table 6}

IV Approach - Robustness Test

This table presents the coefficient estimates of an IV approach. Definitions of all variables can be found in Table 1. Standard errors are clustered by quarter to correct for correlations across banks in the same quarter due to common shocks. ${ }^{* *},{ }^{* *}$, and ${ }^{*}$ correspond to the statistical significance levels of $1 \%, 5 \%$ and $10 \%$, respectively.

\section{Panel A: Ln [SRISK]}

\begin{tabular}{|c|c|c|c|c|c|c|}
\hline \multirow[b]{3}{*}{ Variables } & \multicolumn{2}{|c|}{ 1st stage IV } & \multicolumn{2}{|c|}{ 2nd stage IV } & \multicolumn{2}{|l|}{ OLS } \\
\hline & \multicolumn{2}{|c|}{ LBO exposure } & \multicolumn{2}{|c|}{ Ln [SRISK] } & \multicolumn{2}{|c|}{ Ln [SRISK] } \\
\hline & Coef. & Se. & Coef. & Se. & Coef. & Se. \\
\hline LBO exposure & - & - & $1.34^{* *}$ & $(0.57)$ & $0.35^{* * *}$ & $(0.11)$ \\
\hline $\begin{array}{l}\text { Instrument 1: Ln [mean distance } \\
\text { to PE sponsors of last } 5 \text { years] }\end{array}$ & $-0.03^{* * *}$ & $(0.01)$ & - & - & - & - \\
\hline $\begin{array}{l}\text { Instrument 2: Mean gap PE relation } \\
\text { score to top } 3 \text { relationship banks }\end{array}$ & $-0.74^{* * *}$ & $(0.13)$ & - & - & - & - \\
\hline$\underline{\text { Controls }}$ & & & & & & \\
\hline Count relationships to other banks & $-0.00^{*}$ & $(0.00)$ & 0.00 & $(0.00)$ & 0.00 & $(0.00)$ \\
\hline Ln [number LBO events] & $0.03^{* * *}$ & $(0.01)$ & $0.16^{* *}$ & $(0.07)$ & $0.29^{* * *}$ & $(0.08)$ \\
\hline NBER recession & 0.01 & $(0.00)$ & $0.22^{* * *}$ & $(0.08)$ & $0.26^{* * *}$ & $(0.09)$ \\
\hline Ln [total assets] & $0.04^{* * *}$ & $(0.01)$ & $1.62^{* * *}$ & $(0.09)$ & $1.42^{* * *}$ & $(0.07)$ \\
\hline Syndicated loan market share & $1.82^{* * *}$ & $(0.27)$ & $18.30^{* * *}$ & $(3.53)$ & $18.58^{* * *}$ & (3.33) \\
\hline High yield spread & $0.00^{* *}$ & $(0.00)$ & $0.12^{* * *}$ & $(0.01)$ & $0.13^{* * *}$ & $(0.01)$ \\
\hline Firm fixed effects & \multicolumn{2}{|c|}{ Yes } & \multicolumn{2}{|c|}{ Yes } & \multicolumn{2}{|l|}{ Yes } \\
\hline Observations & \multicolumn{2}{|c|}{2,050} & \multicolumn{2}{|c|}{2,050} & \multicolumn{2}{|c|}{3,538} \\
\hline P-value Sargan-Hansen test & & & \multicolumn{2}{|c|}{0.81} & & \\
\hline Adjusted R-squared & \multicolumn{2}{|c|}{0.79} & \multicolumn{2}{|c|}{0.87} & \multicolumn{2}{|l|}{0.85} \\
\hline
\end{tabular}


Panel B: Ln [SRISK\%]

\begin{tabular}{|c|c|c|c|c|c|c|}
\hline \multirow[b]{3}{*}{ Variables } & \multirow{2}{*}{\multicolumn{2}{|c|}{$\begin{array}{c}\text { 1st stage IV } \\
\text { LBO exposure }\end{array}$}} & \multirow{2}{*}{\multicolumn{2}{|c|}{$\begin{array}{c}\text { 2nd stage IV } \\
\text { Ln [SRISK\%] }\end{array}$}} & \multirow{2}{*}{\multicolumn{2}{|c|}{$\begin{array}{c}\text { OLS } \\
\text { Ln [SRISK\%] }\end{array}$}} \\
\hline & & & & & & \\
\hline & Coef. & Se. & Coef. & Se. & Coef. & Se. \\
\hline LBO exposure & - & - & $1.01^{*}$ & $(0.59)$ & $0.24^{* *}$ & $(0.11)$ \\
\hline \multicolumn{7}{|l|}{ Instrument 1: Ln [mean distance } \\
\hline \multicolumn{7}{|c|}{ Instrument 2: Mean gap PE relationship } \\
\hline \multicolumn{7}{|l|}{ Controls } \\
\hline _Count relationships to other banks & $-0.00^{*}$ & $(0.00)$ & 0.00 & $(0.00)$ & 0.00 & $(0.00)$ \\
\hline Ln [number LBO events] & $0.03^{* * *}$ & $(0.01)$ & $-0.61^{* * *}$ & $(0.07)$ & $-0.59^{* * *}$ & $(0.07)$ \\
\hline NBER recession & 0.01 & $(0.00)$ & $-0.15^{* *}$ & $(0.06)$ & -0.11 & $(0.07)$ \\
\hline Ln [total assets] & $0.04^{* * *}$ & $(0.01)$ & $0.92^{* * *}$ & $(0.11)$ & $0.85^{* * *}$ & $(0.08)$ \\
\hline Syndicated loan market share & $1.82^{* * *}$ & $(0.27)$ & $17.53^{* * *}$ & $(3.92)$ & $16.68^{* * *}$ & $(3.88)$ \\
\hline High yield spread & $0.00^{* *}$ & $(0.00)$ & -0.02 & $(0.01)$ & -0.01 & $(0.01)$ \\
\hline Firm fixed effects & \multicolumn{2}{|c|}{ Yes } & \multicolumn{2}{|c|}{ Yes } & \multicolumn{2}{|c|}{ Yes } \\
\hline Observations & \multicolumn{2}{|c|}{2,050} & \multicolumn{2}{|c|}{2,050} & \multicolumn{2}{|c|}{3,538} \\
\hline P-value Sargan-Hansen test & & & \multirow{2}{*}{\multicolumn{2}{|c|}{$\begin{array}{l}0.39 \\
0.88\end{array}$}} & & \\
\hline Adjusted R-squared & \multicolumn{2}{|c|}{0.79} & & & \multicolumn{2}{|c|}{0.86} \\
\hline
\end{tabular}




\section{Table 7}

Drivers of Impact of LBO Exposure on Systemic Risk

This table presents the coefficient estimates of OLS regressions. Definitions of all variables can be found in Table 1. Standard errors are clustered by quarter to correct for correlations across banks in the same quarter due to common shocks. ${ }^{* *},{ }^{* *}$, and ${ }^{*}$ correspond to the statistical significance levels of $1 \%, 5 \%$ and $10 \%$, respectively.

\begin{tabular}{|c|c|c|c|c|}
\hline \multirow[b]{2}{*}{ Variables } & \multicolumn{2}{|c|}{ Ln [SRISK] } & \multicolumn{2}{|c|}{ Ln [SRISK\%] } \\
\hline & Coef. & Se. & Coef. & Se. \\
\hline LBO exposure & $-3.49^{* *}$ & $(1.50)$ & -1.96 & $(1.24)$ \\
\hline \multicolumn{5}{|l|}{ Interaction terms } \\
\hline LBO exposure \& count relationships to other banks & $0.03^{* * *}$ & $(0.01)$ & $0.02^{*}$ & $(0.01)$ \\
\hline LBO exposure \& ln [total assets] & $0.72^{* * *}$ & $(0.14)$ & $0.56^{* * *}$ & $(0.13)$ \\
\hline LBO exposure \& SIFI bank & $-0.76^{*}$ & $(0.39)$ & -0.58 & $(0.44)$ \\
\hline LBO exposure \& bank sponsor relationship in the past dummy & $-2.71^{* *}$ & $(1.14)$ & $-4.11^{* * *}$ & $(1.11)$ \\
\hline LBO exposure \& ratio lead to participant investments & $-3.16^{* *}$ & $(1.51)$ & $-6.69^{* * *}$ & $(1.41)$ \\
\hline LBO exposure \& bank credit rating & $-0.40^{* * *}$ & $(0.08)$ & $-0.35^{* * *}$ & $(0.08)$ \\
\hline LBO exposure \& borrower credit rating change pre/post loan & $3.95^{* *}$ & $(1.84)$ & 2.87 & $(2.08)$ \\
\hline \multicolumn{5}{|l|}{ Controls } \\
\hline Count relationships to other banks & 0.00 & $(0.00)$ & 0.00 & $(0.00)$ \\
\hline Ln [total assets] & $1.34^{* * *}$ & $(0.09)$ & $0.72^{* * *}$ & $(0.09)$ \\
\hline SIFI bank & $-1.44^{* * *}$ & $(0.47)$ & $-1.50^{* * *}$ & $(0.45)$ \\
\hline Bank sponsor relationship in the past dummy & -0.44 & $(0.30)$ & -0.08 & $(0.27)$ \\
\hline Ratio lead to participant investments & 0.12 & $(0.18)$ & $0.37^{* *}$ & $(0.18)$ \\
\hline Bank credit rating & $-0.06^{* *}$ & $(0.02)$ & -0.03 & $(0.02)$ \\
\hline Borrower credit rating change pre/post loan & $-0.71^{* *}$ & $(0.29)$ & $-0.60^{* *}$ & $(0.29)$ \\
\hline Ln [number LBO events] & $0.17^{* *}$ & $(0.07)$ & $-0.54^{* * *}$ & $(0.08)$ \\
\hline NBER recession & $0.31^{* * *}$ & $(0.08)$ & -0.04 & $(0.08)$ \\
\hline Syndicated loan market share & $21.22^{* * *}$ & $(4.65)$ & $24.96^{* * *}$ & $(4.95)$ \\
\hline High yield spread & $0.11^{* * *}$ & $(0.01)$ & -0.01 & $(0.01)$ \\
\hline Firm fixed effects & \multicolumn{2}{|c|}{ Yes } & \multicolumn{2}{|l|}{ Yes } \\
\hline Observations & \multicolumn{2}{|c|}{1,875} & \multicolumn{2}{|c|}{1,875} \\
\hline Adjusted R-squared & \multicolumn{2}{|c|}{0.87} & \multicolumn{2}{|l|}{0.87} \\
\hline
\end{tabular}




\section{Table 8}

Other Fixed Effects - Robustness Test

This table presents the coefficient estimates of OLS regressions. Definitions of all variables can be found in Table 1 . Standard errors are clustered by quarter to correct for correlations across banks in the same quarter due to common shocks. ${ }^{* *}, * *$, and * correspond to the statistical significance levels of $1 \%, 5 \%$ and $10 \%$, respectively.

\begin{tabular}{|c|c|c|c|c|c|c|c|c|c|c|c|c|}
\hline \multirow[b]{2}{*}{ Variables } & \multicolumn{2}{|c|}{ Ln [SRISK] } & \multicolumn{2}{|c|}{ Ln [SRISK\%] } & \multicolumn{2}{|c|}{ Ln [SRISK] } & \multicolumn{2}{|c|}{ Ln [SRISK\%] } & \multicolumn{2}{|c|}{ Ln [SRISK] } & \multicolumn{2}{|c|}{ Ln [SRISK\%] } \\
\hline & Coef. & Se. & Coef. & Se. & Coef. & Se. & Coef. & Se. & Coef. & Se. & Coef. & Se. \\
\hline LBO exposure & $0.31^{* * *}$ & $(0.11)$ & 0.18 & $(0.11)$ & $0.24^{* *}$ & $(0.12)$ & $0.27^{* *}$ & $(0.12)$ & $0.21^{*}$ & $(0.11)$ & $0.24^{* *}$ & $(0.12)$ \\
\hline \multicolumn{13}{|l|}{$\underline{\text { Controls }}$} \\
\hline Count relationships to other banks & 0.00 & $(0.00)$ & $0.00^{* *}$ & $(0.00)$ & $0.00^{* *}$ & $(0.00)$ & $0.00^{* *}$ & $(0.00)$ & 0.00 & $(0.00)$ & $0.00^{*}$ & $(0.00)$ \\
\hline Ln [number LBO events] & $0.20^{* * *}$ & $(0.07)$ & $-0.64^{* * *}$ & $(0.07)$ & -0.06 & $(0.13)$ & 0.03 & $(0.09)$ & -0.06 & $(0.13)$ & 0.02 & $(0.09)$ \\
\hline NBER recession & $0.30^{* * *}$ & $(0.08)$ & -0.09 & $(0.07)$ & $0.24^{* * *}$ & $(0.08)$ & -0.01 & $(0.05)$ & $0.26^{* * *}$ & $(0.08)$ & 0.01 & $(0.06)$ \\
\hline Ln [total assets] & $1.49^{* * *}$ & $(0.07)$ & $0.90^{* * *}$ & $(0.08)$ & $1.10^{* * *}$ & $(0.08)$ & $1.10^{* * *}$ & $(0.08)$ & $1.26^{* * *}$ & $(0.08)$ & $1.26^{* * *}$ & $(0.08)$ \\
\hline Syndicated loan market share & $15.16^{* * *}$ & $(3.40)$ & $14.57^{* * *}$ & $(3.92)$ & $13.25^{* * *}$ & $(3.54)$ & $13.30^{* * *}$ & $(3.64)$ & $11.98^{* * *}$ & (3.56) & $12.03^{* * *}$ & $(3.67)$ \\
\hline High yield spread & $0.12^{* * *}$ & $(0.01)$ & -0.01 & $(0.01)$ & $0.07^{* * *}$ & $(0.03)$ & 0.02 & $(0.02)$ & $0.08^{* * *}$ & $(0.03)$ & 0.02 & $(0.02)$ \\
\hline Firm fixed effects & \multicolumn{2}{|c|}{ Yes } & \multicolumn{2}{|c|}{ Yes } & \multicolumn{2}{|c|}{ Yes } & \multicolumn{2}{|c|}{ Yes } & \multicolumn{2}{|c|}{ Yes } & \multicolumn{2}{|l|}{ Yes } \\
\hline Rating fixed effects & \multicolumn{2}{|l|}{ Yes } & \multicolumn{2}{|c|}{ Yes } & \multicolumn{2}{|l|}{ No } & \multicolumn{2}{|c|}{ No } & \multicolumn{2}{|c|}{ Yes } & \multicolumn{2}{|l|}{ Yes } \\
\hline Year fixed effects & \multicolumn{2}{|l|}{ No } & \multicolumn{2}{|c|}{ No } & \multicolumn{2}{|l|}{ Yes } & \multicolumn{2}{|c|}{ Yes } & \multicolumn{2}{|c|}{ Yes } & \multicolumn{2}{|c|}{ Yes } \\
\hline Observations & \multicolumn{2}{|c|}{3,538} & \multicolumn{2}{|c|}{3,538} & \multicolumn{2}{|c|}{3,538} & \multicolumn{2}{|c|}{3,538} & \multicolumn{2}{|c|}{3,538} & \multicolumn{2}{|c|}{3,538} \\
\hline Adjusted R-squared & \multicolumn{2}{|l|}{0.86} & \multicolumn{2}{|c|}{0.86} & \multicolumn{2}{|c|}{0.86} & 0.87 & & 0.87 & & 0.87 & \\
\hline
\end{tabular}




\section{Table 9}

Autocorrelation - Robustness Test

This table presents the coefficient estimates of OLS regressions. Definitions of all variables can be found in Table 1. Standard errors are clustered by quarter to correct for correlations across banks in the same quarter due to common shocks. ${ }^{* *},{ }^{* *}$, and ${ }^{*}$ correspond to the statistical significance levels of $1 \%, 5 \%$ and $10 \%$, respectively.

\begin{tabular}{|c|c|c|c|c|}
\hline \multirow[b]{2}{*}{ Variables } & \multicolumn{2}{|c|}{$\Delta(\operatorname{Ln}[$ SRISK] $)$} & \multicolumn{2}{|c|}{$\Delta(\operatorname{Ln}[S R I S K \%])$} \\
\hline & Coef. & Se. & Coef. & Se. \\
\hline$\Delta(\mathrm{LBO}$ exposure $)$ & $0.50^{* *}$ & $(0.24)$ & $0.57^{* *}$ & $(0.22)$ \\
\hline \multicolumn{5}{|l|}{ Controls } \\
\hline Lagged dependent variable & $-0.31^{* * *}$ & $(0.04)$ & $-0.44^{* * *}$ & $(0.04)$ \\
\hline$\Delta$ (Count relationships to other banks) & $-0.01^{*}$ & $(0.01)$ & -0.01 & $(0.01)$ \\
\hline$\Delta($ Ln [number LBO events] $)$ & -0.12 & $(0.10)$ & -0.07 & $(0.04)$ \\
\hline$\Delta$ (NBER recession) & 0.11 & $(0.07)$ & -0.02 & $(0.06)$ \\
\hline$\Delta(\operatorname{Ln}$ [total assets] $)$ & $0.64^{* * *}$ & $(0.22)$ & 0.17 & $(0.18)$ \\
\hline$\Delta($ Syndicated loan market share $)$ & 14.93 & $(10.23)$ & $21.62^{* *}$ & $(8.25)$ \\
\hline$\Delta($ High yield spread $)$ & $0.05^{* *}$ & $(0.02)$ & $0.03^{* * *}$ & $(0.01)$ \\
\hline Firm fixed effects & \multicolumn{2}{|c|}{ Yes } & \multicolumn{2}{|l|}{ Yes } \\
\hline Observations & \multicolumn{2}{|c|}{3,373} & \multicolumn{2}{|l|}{3,373} \\
\hline Adjusted R-squared & \multicolumn{2}{|c|}{0.21} & \multicolumn{2}{|l|}{0.24} \\
\hline
\end{tabular}




\section{Table 10}

U.S.-Aggregated Impact of LBO Exposure on Systemic Risk

This table presents the coefficient estimates of OLS regressions. Definitions of all variables can be found in Table 1. Standard errors are clustered by quarter to correct for correlations across banks in the same quarter due to common shocks. ${ }^{* *},{ }^{* *}$, and ${ }^{*}$ correspond to the statistical significance levels of $1 \%, 5 \%$ and $10 \%$, respectively.

\begin{tabular}{lrrrr} 
& \multicolumn{2}{c}{ CATFIN } & \multicolumn{2}{c}{ CATFIN } \\
Variables & Coef. & Se. & Coef. & Se. \\
\hline & & & & \\
Aggregated LBO exposure & $2.42^{* * *}$ & $(0.43)$ & $5.54^{* * *}$ & $(1.77)$ \\
& & & & \\
Controls & & & & \\
Aggregated takeover exposure & - & - & $2.43^{*}$ & $(1.41)$ \\
Aggregated recapitalization exposure & - & - & -0.09 & $(0.66)$ \\
Aggregated miscellaneous exposure & - & - & 1.04 & $(0.97)$ \\
NBER recession & $0.14^{* * *}$ & $(0.04)$ & 0.07 & $(0.05)$ \\
High yield spread & $0.01^{* * *}$ & $(0.01)$ & -0.01 & $(0.01)$ \\
Aggregated HHI & 6.42 & $(4.14)$ & 0.54 & $(3.79)$ \\
\hline Observations & 50 & & 50 & \\
Adjusted R-squared & 0.44 & & 0.52 & \\
\hline
\end{tabular}




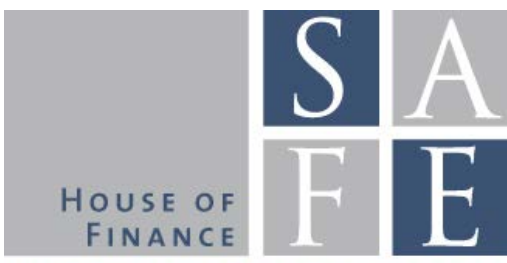

WORKING PAPER SERIES

\section{Recent Issues}

No. $100 \quad$ Marcel Grupp

No. 99 Marcel Grupp, Christian Rauch, Marc Umber, Uwe Walz

No. 98 Tobias Niedrig, Helmut Gründl

No. 97 Tobias Niedrig

No.96 Jens-Hinrich Binder

No. 95 Loriana Pelizzon, Marti G. Subrahmanyam, Davide Tomio, Jun Uno

No. 94 Claudia Lambert, Felix Noth, Ulrich Schüwer

No. 93 Shafik Hebous, Tom Zimmermann

No.92 Christoph Hambel, Holger Kraft, Eduardo S. Schwartz

No.91 Anne-Caroline Hüser

No. $90 \quad$ Pinar Topal

No. 89 Julia Braun, Alfons J. Weichenrieder

No. 88 Ester Faia, Beatrice Weder di Mauro
Taking the Lead: When Non-Banks Arrange Syndicated Loans

The Influence of Leveraged Buyouts on Target Firms' Competitors

The Effects of Contingent Convertible (CoCo) Bonds on Insurers' Capital Requirements Under Solvency II

Optimal Asset Allocation for interconnected Life Insurers in the Low Interest Rate Environment under Solvency Regulation

Banking Union and the Governance of Credit Institutions - A Legal Perspective

Sovereign Credit Risk, Liquidity, and ECB Intervention: Deus Ex Machina?

How Do Banks React to Catastrophic Events? Evidence from Hurricane Katrina

Revisiting the Narrative Approach of Estimating Tax Multipliers

Optimal Carbon Abatement in a Stochastic Equilibrium Model with Climate Change

Too Interconnected to Fail: A Survey of the Interbank Networks Literature

Fiscal Stimulus and Labor Market Flexibility

Does Exchange of Information between Tax Authorities Influence Multinationals' Use of Tax Havens?

Cross-Border Resolution of Global Banks 